(2019) 25 JUUM 47 - 52

https://doi.org./10.17576/juum-2019-25-06

\title{
Harmonizing Trade Laws in South Asia: A Future Thought
}

\author{
MD. HABIB ALAM
}

\begin{abstract}
International trade law is one of the key factors for economic development for a country or regional development. The South Asian Association for Regional Cooperation (SAARC) is one of the Southern Associations which consists of 8 countries. SAARC follows the same trend of "Sustainable trade." Sustainable trade depends on the globalization of trade. Globalization of trade depends on uniformity. Uniformity may be two types, regional uniformity (i.e. SAARC) and multi-regional uniformity (i.e. a combination of more than one regional uniformity, like CISG). This research is on SAARC (i.e. regional uniformity) to harmonize the trade laws. SAARC states have different treaties (i.e. bilateral treaties, oral agreements, business usages, may have different publicly known or unknown agreements linking with arbitration etc.). These different instruments or laws may give rise to conflicts of laws within SAARC states. Judges of different jurisdictions of SAARC may interpret in different ways and complexity in trade laws will increase. It will help involving more expenditure (i.e. long procedure to solve the disputes, hiring foreign lawyers, expertise expenditure etc.). The main objective of this research is as to how we can harmonize the trade laws within the SAARC region by complying with international standard in every jurisdiction of SAARC states. This research provides an idea that we need to form a new uniform sale law like CISG for sustainable trade within SAARC states.
\end{abstract}

Keywords: Harmonization of trade laws; treaties; SAARC; CISG; uniformity

\section{INTRODUCTION}

The South Asian Association for Regional Cooperation (SAARC) was formed by signing SAARC Charter in Dhaka on 8 December 1985. Afghanistan, Bangladesh, Bhutan, India, Maldives, Nepal, Pakistan are signing parties of SAARC. They are also known as South Asian countries. One of the objectives of SAARC is to promote economic growth in South Asian Countries. ${ }^{1,2}$ Promoting economic growth may act as "impacting or influential catalyst" for other objectives (i.e. improve quality of life, social progress, culture development etc. $)^{3}$ of SAARC for sustainable development of SAARC.

\section{FUNCTION OF SAARC}

To know the function of SAARC, we need to consider a deep analysis of "Charter of the South Asians Association for Regional Co-operation."

SAARC Charter consists of 10 Articles (Articles I $-\mathrm{X})$. The preamble of SAARC Charter emphasized on 8 points. ${ }^{4}$

The preamble of SAARC Charter enhances to promote peace, stability, amity and progress without any non-discriminating interferences with any SAARC members' jurisdictional issues (i.e. curtalation of sovereignty). The preamble of SAARC charter treats SAARC as an interdepended regional entity and part of the interdepended world. ${ }^{5}$ 'Mutual understanding and neighbour nexus principles' are tools for achieving the goal of interdepended regional entity for SAARC nations. ${ }^{6}$
Mutual understanding may include joint action, co-operation, exchange procedure, mutual benefits. Neighbour nexus principle exists through political, economic and cultural traditions. Neighbour nexus may include desirability (i.e. welfare and quality of life) and friendship relationship (i.e. trustworthy relationship ${ }^{7}$ ). ${ }^{8}$

The preamble of SAARC should be read with other 'Articles I-X' of SAARC Charter.

Article I of SAARC Charter provides objectives of the SAARC. The objectives of SAARC are to improve living standard with SAARC states, to boost 'economic, social and cultural progress,' emphasizing on active 'self-reliance and mutual understanding/common interest,' linking with different international and regional organizations to enhance the real objectives of SAARC. ${ }^{9}$

Article II deals with 'co-operation procedure' among the SAARC region. Cooperation should not affect the sovereignty of any nation within the SAARC region. Co-operation should not add or inconsistency with treaties (i.e. bilateral and multilateral treaties) but shall complement bilateral or multilateral treaties. ${ }^{10}$

Relevant authorities of each member states should meet once or more in each year subject to the necessity to discuss different issues of SAARC. ${ }^{11}$

Article IV of SAARC may be termed as 'Policies making procedure by the council of ministers.' Foreign ministries of different jurisdictions of the SAARC region will meet twice a year to draft policies for SAARC. Ministers will scrutinize different sustainable issues (i.e. new area, matters of general interest, additional mechanism etc.) for drafting sustainable policies of SAARC. ${ }^{12}$ 
Under Article V of SAARC, Standing committee acts as "watchdog or linking authority." Functions of the standing committee are to monitor and coordinate different internal and external regional matters (i.e. projects and programmes). ${ }^{13}$

Article VI may be considered as "effectiveness policies implementation procedure" by Technical Committees. This Article will be divided into two parts, i.e. theoretical approach for implementation of policies and practical approach for implementation of policies. ${ }^{14}$

Article VI (2)(e) of SAARC Charter may be considered under a practical approach for implementation of policies. Article VI (2) (e) provides "implementation and coordination of sectoral programmes." 15

Other than Article VI (2)(e) of SAARC Charter, all other Article VI (2)(a)-(d),(f) and Article VI (3),(4),(5) may be considered under theoretical approach for implementation of policies. ${ }^{16}$

Technical committees monitor and coordinate different projects and programmes under Article VI of SAARC Charter. These may be termed as "theoretical approach for implementation of policies."

Article VII of SAARC deals with "implementation procedure" where action committees implement projects for SAARC nations. ${ }^{18}$

Article VIII of SAARC provides the opportunity to an eligible individual to be a secretary for the SAARC. ${ }^{19}$

Article IX of SAARC provides as to how the financial arrangement of SAARC should be arranged by taking consideration of different issues (i.e. the contribution of each member state, recommendations, sufficient financial resources etc.). ${ }^{20}$

All decision of SAARC related issues should be decided on the basis of unanimity by excluding any bilateral and contentious resources issues (Article X of SAARC Charter). ${ }^{21}$

Next heading, we will observe as to how SAARC is engaged in developing trade with the SAARC nations.

\section{FUTURE THOUGHT FOR TRADE BY SAARC COMMUNITY}

Amjad Hussain B. Sial (Secretary General of SAARC) emphasized on "collaboration among businessmen and civil society" and this collaboration is linked with trade practice among SAARC nations. ${ }^{22}$

SAARC desires to achieve its goal of successful South Asian Economic Union (SAEU) through a common market, common economic and monetary union. ${ }^{23}$ To observe more, it needs to examine the insider thought of South Asian Economic Union (SAEU), i.e. "Next Steps to South Asian Economic Union". ${ }^{24}$

South Asian Economic Union aims at achieving the goal of "globalization in trade" by combining different Agreements and co-operation procedures, i.e. Agreement on South Asian Free Trade Area (SAFTA), Regional cooperation and integration (RCI) etc. ${ }^{25}$
SAEU considers different progressive and relationship procedures among SAARC states to improve trade among SAARC nations. Regional Economic Integration (Phase I) was based on 4 pillars, i.e. market integration, crossborder connectivity, energy cooperation and private sector liberalization. ${ }^{26}$

The second phase of Regional Economic Integration (REI) will be considered as a considerable tool for achieving the goal of SAEU. ${ }^{27}$

Legal scholars argued to consider different international organization's (i.e. EU, ASEAN and renowned international organizations) approaches to achieve the goal of SAEU. ${ }^{28}$

For regional co-operation and integration, SAARC may consider different factors and approaches, i.e. Topdown approaches based on binding agreements (i.e. SAFTA) and regional practices by different organizations (i.e. SAARC and ASEAN), 'cross-border and globalized market' approaches, geographical focused issues etc. ${ }^{29}$

All the above $4 \mathrm{RCI}$ approaches are used for "reinforcement procedure" by taking consideration of private and public sector business interest. ${ }^{30}$

SAARC may get an idea from "ASEAN approach," ASEAN Economic Community (AEC) is considered as a Free Trade Area (FTA) and model by removing trade barriers (i.e. Barriers to the movement of goods, capital, labour, services and tax-related issues etc.). ${ }^{31}$

For trade liberalization, SAARC considers different factors, i.e. Forming trade facilitation committees, taking consideration of different organizations (WTO, Asian Development Bank, World Bank, United Nations Economic and Social Commission for Asian and the Pacific, and other organizations), active involvement with different commercial organizations and issues, active participation in trade measures, tailoring trade measures, introducing monitoring systems, built strong Information Technology system for trade (i.e. paperless trade, e-filing etc.), building filtering procedure (i.e. streaming, monitoring etc.), forming different "harmonization approaches" for different issues of trade etc. ${ }^{32}$

The aim of SAEU is to harmonize the trade among SAARC nations through achieving a goal for "sustainable trade development" by removing all trade barriers. ${ }^{33}$ SAARC emphasizes on "harmonization of a standard" to develop 'uniformity of trade' within SAARC nations. Harmonization of international trade law is one of the key issues for achieving 'uniformity of trade' among SAARC nations. The important of harmonization of international trade law will be discussed in the next heading.

\section{NECESSITY FOR HARMONIZING INTERNATIONAL TRADE LAW}

To ensure certainty for a particular field, international convention (i.e. CISG) may be considered as an essential tool for harmonization of law among particular region 
(i.e. SAARC). ${ }^{34}$ Harmonization of trade law may be taken place in three ways: ${ }^{35}$

1. Through international instrument. ${ }^{36}$

2. through transplantation of foreign law. ${ }^{37}$

3. hybrid of above two which may be adopted by an internationally agreed model law. ${ }^{38}$

Lord Mansfield stated that "The mercantile law, in this respect is the same all over the world. For far from the same premises, the same conclusion of reason and justice must universally be the same." ${ }^{" 39}$

Sources of international trade law are based on legal authority (i.e. statutes, judicial decisions and international conventions etc.) ${ }^{40}$ Complexity may arise due to different interpretations (i.e. conflict of laws) for different legal authorities for a particular case. It may be solved through uniformity of laws (i.e. interpretation based on the international standard). Harmonization of law is a part of the uniformity of law.

Harmonization of trade law may be achieved by two models, i.e. public law level (i.e. when CISG is applied between states) and Private law level (i.e. when CISG is applied between state and private legal entity/ individual). ${ }^{41}$

Legal scholars including businessmen and trade associations agreed for harmonization of trade laws need to cope up with international standard in every jurisdiction..$^{42}$

Understanding international trade laws are limited to a small group in the world. Different jurisdictions have different laws. It may give rise to "conflicts of laws." The minimizing of the laws may be done through the uniformity of laws (i.e. CISG). This is necessary for the improvement of harmonizing or uniformity of international trade law. ${ }^{43}$

Harmonization of trade laws is necessary for uniformity of trade law and sustainable development of global trade. Harmonizing laws may be considered as the second highest key factor in saving costs. ${ }^{44}$ Similar "legal thought" may be applied for harmonization of international trade laws among SAARC region.

Transaction cost is one of the key issues for international trade law. ${ }^{45}$ Many states are unable to compete with foreign trade nations (i.e. developed states) due to the foreignness of laws. For Example, A (Bangladeshi trader) contracts with B (USA trader) to sell goods. If any dispute arises, then USA trader may try to solve the dispute by applying their domestic law (i.e. $\mathrm{UCC}) .^{46}$ If Bangladesh signs $\mathrm{CISG}^{47}$ and becomes CISG contracting state, then both Bangladeshi trader and USA trader may use CISG to make both the parties on "equal footing." It will reduce transaction cost by not hiring any foreign expert or no need to apply any foreign law.

Legal scholar suggested CISG may reduce transaction cost for different jurisdictional transnational transactions (i.e. Article 2 of OHADA uniform laws regime viewed the same notion) ${ }^{48}$ The same approach may be applied in SAARC by forming a new type of uniform sale contract.
It may be termed as "Block Chain Uniform Sale Contract for SAARC Region." 49

Promoting economic growth means improving trade laws among SAARC member states. In SAARC member states' trade laws may be different from interpretation perspectives. For different interpretations among SAARC nations, trade disputes may arise. To minimize interpretations relating to differences, "harmonization of trade laws" among SAARC nations is necessary. ${ }^{50}$

SAARC nations have a different political and ideological school of thoughts like developed nations. Trust and understanding are important issues for the development of peaceful trade by avoiding any armed conflicts. To reach this goal in the SAARC region, the harmonization of trade law is an essential impacting factor for the development of trade in the SAARC region. ${ }^{51}$

\section{GLOBAL JURISCONSULTORIUM FOR HARMONIZATION OF TRADE LAW}

It was suggested that, in the case, Fothergill v Monarch Airlines, the House of Lords stated that the international law should be treated as unique law. World business law depends on the global Jurisconsultorium because by harmonization that law can be applied in different jurisdictions. Another reason for its relevance is that there is no international business court which can deal with international trade law disputes ${ }^{52}$ thus, global jurisconsultorium removes the barrier to the harmonization of the law to run international trade law smoothly in all jurisdictions by keeping the disputed parties on equal footing. ${ }^{53}$

The above suggestion is also applicable to the harmonization of trade laws among SAARC nations. The interpretation of trade disputes cases depends on the judge's attitude or arbitrators. They should interpret the trade disputes cases in international standard, i.e. Article 7(1) of CISG provides "In the interpretation of this Convention, regard is to be had to its international character and to the need to promote uniformity in its application and the observance of good faith in international trade." 54

\section{SAARC TREATIES}

SAARC has two types of trade agreements, i.e. SAARC agreements and bilateral treaties. ${ }^{55}$

SAARC has regional treaties among SAARC nations, i.e. SAARC Agreement on Trade in Services (SATISI), Agreement on South Asian Free Trade Area (SAFTA), and Agreement on SAARC Preferential Trading Arrangement (SAPTA) ${ }^{56}$

Besides Regional Treaties, SAARC nations signed different bilateral trade treaties, i.e. Afghanistan-India Preferential Trade Agreement, Afghanistan-Pakistan Transit Trade Agreement, Bangladesh-Bhutan Agreement 
on Trade, India-Bangladesh Trade Agreement, IndiaBhutan Trade Agreement, India-Nepal Trade Treaty, India-Sri Lanka Free Trade Agreement and Pakistan-Sri Lanka Free Trade agreement. ${ }^{57}$

The main objectives for both SAARC regional agreements and bilateral treaties are:

1. To promote and develop trade among contracting states;

2. To put the contracting states on equal footing;

3. The Contracting States should have the opportunity for negotiations and fulfilment of special commitments;

4. Emphasizing on the "positive list approach" and "request-and-offer" approach;

5. To promote fair trading among contracting states by eliminating transnational trade barriers;

6. To form an effective mechanism and framework for practical implementation and application of agreements. This may be termed as "Effective Mechanism Procedure";

7. To ensure free movements of goods. Goods may include any products, Vehicles, vessels, transports etc. unless specific goods are illegal by any particular jurisdiction or barred by the competent forum of competent jurisdiction;

8. To minimize fraudulent practice among contracting states;

9. To provide reasonable concession on export or import of goods subject to mutual understanding and good faith among contracting states.

\section{POLICIES FOR IMPLEMENTATION OF FUTURE THOUGHT FOR HARMONISATION OF TRADE LAWS AMONG SAARC}

SAARC may consider different policies for harmonization of trade laws within SAARC nations.

ASEAN adopted ATIGA in February 2009 and came into enforce on 17 May 2010. ${ }^{58}$ The main objectives of ATIGA are to form "an integrated market" and "free flow of goods." ${ }^{\circ 9}$ A similar approach may be followed by SAARC states.

An integrated market is where a preferential trade area (i.e. SAARC, ASEAN, and EU) is selected. This selected trade region may be termed as "regional trading bloc." A regional trading block consists of different countries within a geographical region. ${ }^{60}$ There can be different stages of integration. For better understanding, a figure is provided below which is taken from 'Economics Online, UK' directly. ${ }^{61}$

Free flow of goods means it will provide free trade zone $^{63}$ for conducting trade and by avoiding trade barriers within a region (i.e. SAARC Region). ${ }^{64}$ The preamble of CISG emphasizes to remove the legal barrier in international trade for the development of international trade law. ${ }^{65}$ SAARC may consider drafting similar uniform

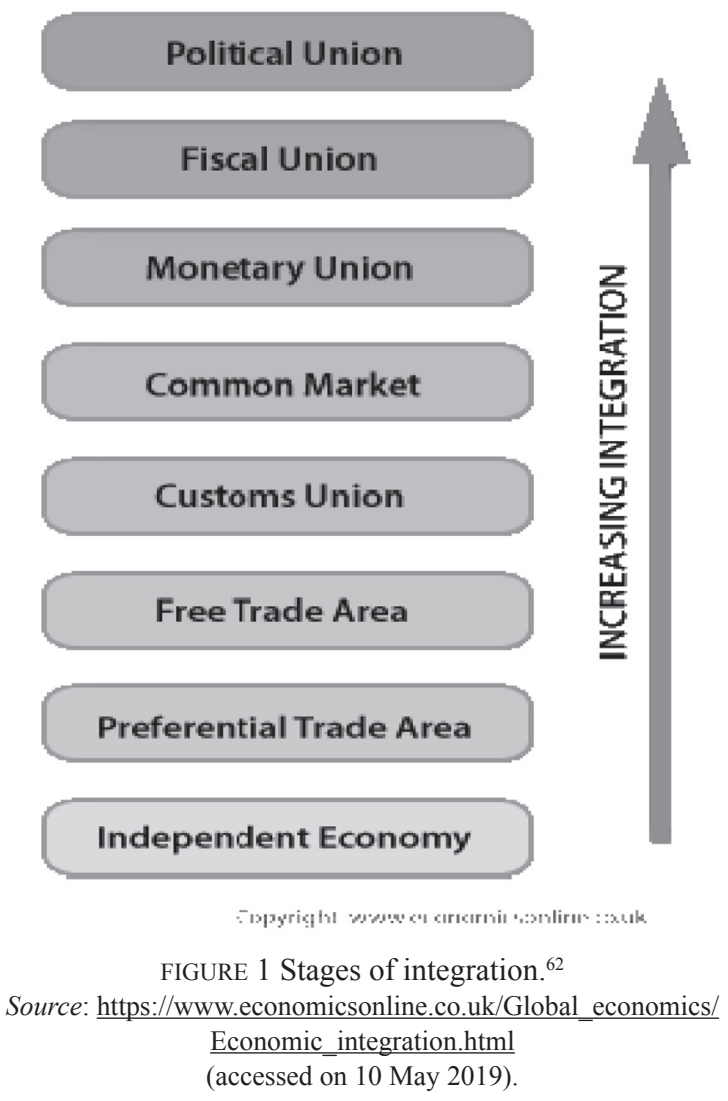

laws (i.e. ATIGA, CISG etc.) for harmonization of trade laws for SAARC region. ${ }^{66}$

Organisation for the Harmonization of Business Law in Africa ${ }^{67}$ (OHADA) is an organization for harmonization of Business Law. OHADA uniform Acts include different uniform acts (i.e. arbitration law, general commercial law, co-operatives, etc.) ${ }^{68}$

Legal scholars suggested the uniform acts are directly applicable and may override the domestic laws of a particular jurisdiction. Uniform acts will strength the internal trade market within a region. ${ }^{69}$

SAARC may consider Uniform acts (i.e. OHADA uniform acts and Uniform laws (i.e. CISG) for harmonization of trade laws for SAARC region. ${ }^{70}$

\section{CONCLUSION}

To fulfil the above-mentioned objectives, the harmonization of trade laws is essential among SAARC nations. SAARC may take some necessary steps to harmonize the trade laws among contracting states, i.e.:

1. Taking consideration of 'trade facilitation measures' by minimizing physical and non-physical trade barriers within the SAARC region. ${ }^{71}$ It will work combining with SAARC Uniform Sales Law.

2. Combine work of policymakers and researchers to find the solution for gap filling procedure for harmonization of trade laws among SAARC region and draft a new sales law for SAARC. ${ }^{72}$ 
3. To form Uniform Trade Laws (i.e. Like CISG which is considered as harmonizing and uniformity tool $)^{73}$ for SAARC nations;

4. To form a case law e-Repository for SAARC nations $;{ }^{74}$

5. To form a separate uniform commercial court for SAARC nationals for solving trade disputes through "fast track procedure," i.e. Singapore International Commercial Court. ${ }^{75}$

\section{NOTES}

http://saarc-sec.org/about-saarc (Accessed on 24 October 2018). http://saarc-sec.org/about-saarc (Accessed on 24 October 2018). http://saarc-sec.org/saarc-charter (accessed on 8 May 2019). http://saarc-sec.org/saarc-charter (accessed on 8 May 2019). http://saarc-sec.org/saarc-charter (accessed on 8 May 2019).

6 Jonathan Anomaly, Trust, Trade, and Moral progress: How Market Exchange Promotes Trustworthiness. Website: https://www. cambridge.org/core/journals/social-philosophy-and-policy/article/ trust-trade-and-moral-progress-how-market-exchange-promotes-tr ustworthiness/754AE9CC310707172ABF5B719787E41B

http://saarc-sec.org/saarc-charter (accessed on 8 May 2019).

8 http://saarc-sec.org/saarc-charter (accessed on 8 May 2019).

http://saarc-sec.org/saarc-charter (accessed on 8 May 2019).

$10 \mathrm{http}: / /$ saarc-sec.org/saarc-charter (accessed on 8 May 2019).

1 http://saarc-sec.org/saarc-charter (accessed on 8 May 2019).

$12 \mathrm{http}: / /$ saarc-sec.org/saarc-charter (accessed on 8 May 2019).

$3 \mathrm{http}: / /$ saarc-sec.org/saarc-charter (accessed on 8 May 2019).

$4 \mathrm{http} / / /$ saarc-sec.org/saarc-charter (accessed on 8 May 2019).

$5 \mathrm{http} / / /$ saarc-sec.org/saarc-charter (accessed on 8 May 2019).

$6 \mathrm{http} / / /$ saarc-sec.org/saarc-charter (accessed on 8 May 2019).

$17 \mathrm{http}: / /$ saarc-sec.org/saarc-charter (accessed on 8 May 2019).

$8 \mathrm{http}: / /$ saarc-sec.org/saarc-charter (accessed on 8 May 2019).

$19 \mathrm{http}: / /$ saarc-sec.org/saarc-charter (accessed on 8 May 2019).

20 http://saarc-sec.org/saarc-charter (accessed on 8 May 2019).

21 Thirty-Fourth SAARC Charter Day. Website: http://saarc-sec. org/assets/responsive_filemanager/source/Charter\%20Day $\% 20$ Messages/2018/Saarc.pdf (accessed on 9 May 2019).

$22 \mathrm{http} / /$ saarc-sec.org/areas_of_cooperation/area_detail/economictrade-and-finance/click-for-details_7 (accessed on 9 May 2019).

23 Next steps to South Asian Economic Union: A Study on Regional Economic Integration (Phase II) Commissioned by the SAARC Secretariat. Website: http://www.sasec.asia/uploads/publications/ next-steps-to-saeu.pdf (accessed on 9 May 2019).

24 Next steps to South Asian Economic Union: A Study on Regional Economic Integration (Phase II) Commissioned by the SAARC Secretariat. Website: http://www.sasec.asia/uploads/publications/ next-steps-to-saeu.pdf (accessed on 9 May 2019).

25 Next steps to South Asian Economic Union: A Study on Regional Economic Integration (Phase II) Commissioned by the SAARC Secretariat. Website: http://www.sasec.asia/uploads/publications/ next-steps-to-saeu.pdf (accessed on 9 May 2019).

26 Next steps to South Asian Economic Union: A Study on Regional Economic Integration (Phase II) Commissioned by the SAARC Secretariat. Website: http://www.sasec.asia/uploads/publications/ next-steps-to-saeu.pdf (accessed on 9 May 2019).

27 Next steps to South Asian Economic Union: A Study on Regional Economic Integration (Phase II) Commissioned by the SAARC Secretariat. Website: http://www.sasec.asia/uploads/publications/ next-steps-to-saeu.pdf (accessed on 9 May 2019).

28 Next steps to South Asian Economic Union: A Study on Regional Economic Integration (Phase II) Commissioned by the SAARC Secretariat. Website: http://www.sasec.asia/uploads/publications/ next-steps-to-saeu.pdf (accessed on 9 May 2019).

29 Next steps to South Asian Economic Union: A Study on Regional Economic Integration (Phase II) Commissioned by the SAARC
Secretariat. Website: http://www.sasec.asia/uploads/publications/ next-steps-to-saeu.pdf (accessed on 9 May 2019).

30 Next steps to South Asian Economic Union: A Study on Regional Economic Integration (Phase II) Commissioned by the SAARC Secretariat. Website: http://www.sasec.asia/uploads/publications/ next-steps-to-saeu.pdf (accessed on 9 May 2019).

31 Next steps to South Asian Economic Union: A Study on Regional Economic Integration (Phase II) Commissioned by the SAARC Secretariat. Website: http://www.sasec.asia/uploads/publications/ next-steps-to-saeu.pdf (accessed on 9 May 2019).

32 Next steps to South Asian Economic Union: A Study on Regional Economic Integration (Phase II) Commissioned by the SAARC Secretariat. Website: http://www.sasec.asia/uploads/publications/ next-steps-to-saeu.pdf (accessed on 9 May 2019).

33 Next steps to South Asian Economic Union: A Study on Regional Economic Integration (Phase II) Commissioned by the SAARC Secretariat. Website: http://www.sasec.asia/uploads/publications/ next-steps-to-saeu.pdf (accessed on 9 May 2019).

34 Marlene Wethmar-Lemmer, Regional Harmonization of international sales law via the accession of the CISG and the importance of uniform interpretation of the CISG. Website: https://home. heinonline.org/ (accessed on 6 March 2019).

35 Bruno Zeller, The significance of the Vienna Convention on the International Sale of Goods for the Harmonization and transplantation of international commercial law. https://home. heinonline.org/ (accessed on 6 March 2019).

36 Bruno Zeller, The significance of the Vienna Convention on the International Sale of Goods for the Harmonization and transplantation of international commercial law. https://home. heinonline.org/ (accessed on 6 March 2019).

37 Bruno Zeller, The significance of the Vienna Convention on the International Sale of Goods for the Harmonization and transplantation of international commercial law. https://home. heinonline.org/ (accessed on 6 March 2019).

38 Bruno Zeller, The significance of the Vienna Convention on the International Sale of Goods for the Harmonization and transplantation of international commercial law. https://home. heinonline.org/ (accessed on 6 March 2019).

39 Bruno Zeller, The significance of the Vienna Convention on the International Sale of Goods for the Harmonization and transplantation of international commercial law. https://home. heinonline.org/ (accessed on 6 March 2019).

40 Pamela Sellman, Revision Workbook: Law of International Trade, $4^{\text {th }}$ Edn, Old Baily Press, UK, 2006, p. ix.

41 Bruno Zeller and Janko Nikolic, Trade Harmonisation-How Harmonised is it? Website: https://home.heinonline.org/ (accessed on 6 March 2019).

42 Roy Goode, Herbert Kronke and Ewan Mckendrick, Transnational Commercial Law, $2^{\text {nd }}$ Edn, Oxford University Press, 2015, p.163.

43 Roy Goode, Herbert Kronke and Ewan Mckendrick, Transnational Commercial Law, $2^{\text {nd }}$ Edn, Oxford University Press, 2015, pp. 163 164.

44 Bruno Zeller and Janko Nikolic, Trade Harmonisation-How Harmonised is it? Website: https://home.heinonline.org/ (accessed on 6 March 2019)

45 Bruno Zeller and Janko Nikolic, Trade Harmonisation-How Harmonised is it? Website: https://home.heinonline.org/ (accessed on 6 March 2019).

46 https://www.michigan.gov/documents/en tireuccbook_18831_7.pdf (accessed on 15 December 2018).

47 https://www.uncitral.org/pdf/english/texts/ sales/cisg/V1056997CISG-e-book.pdf (Accessed on 15 December 2018

48 Bruno Zeller and Janko Nikolic, Trade Harmonisation-How Harmonised is it? Website: https://home.heinonline.org/ (accessed on 6 March 2019).

49 Bruno Zeller and Janko Nikolic, Trade Harmonisation-How Harmonised is it? Website: https://home.heinonline.org/ (accessed on 6 March 2019). 
50 Roy Goode, Herbert Kronke and Ewan Mckendrick, Transnational Commercial Law, $2^{\text {nd }}$ Ed., Oxford University Press, 2015, pp.163-164

51 Roy Goode, Herbert Kronke and Ewan Mckendrick, Transnational Commercial Law, $2^{\text {nd }}$ Ed., Oxford University Press, 2015, pp. $163-$ 164.

52 Camilla Andersen, The Global Jurisconsultorium of the CISG Revisited http://www.cisg.law.pace.edu/cisg/biblio/andersen7.html (accessed on 13 May 2015).

53 A case for Bangladesh's accession to the UN Sale Convention: A critical study from Policy and Legal Perspective, p. 105. Faculty of law, National University of Malaysia (UKM), 2018.

54 https://www.uncitral.org/pdf/englis h/texts/sales/cisg/V1056997CISG-e-book.pdf (accessed on 24 October 2018).

55 https://www.saarcchamber.org (accessed on 24 October 2018).

56 https://www.saarcchamber.org/index.php?option=com_content\&vi $\mathrm{ew}=$ article $\& \mathrm{id}=374 \&$ Itemid $=500$ (accessed on 24 October 2018).

57 https://www.saarcchamber.org/index.ph p?option=com_content\&vi $\mathrm{ew}=$ article $\& \mathrm{id}=375 \&$ Itemid $=501 \#$ (accessed on 24 October 2018)

58 https://www.miti.gov.my/miti/resour ces/fileupload/Write-up\%20 on $\% 20$ ASEAN $\%$ 20Trade $\% 20$ in $\% 20$ Goods $\% 20$ Agreement $\% 20$ (ATIGA).pdf (accessed on 10 May 2019).

59 https://www.miti.gov.my/miti/resourc es/fil eupload/Write-up $\% 20$ on $\% 20$ ASEAN $\% 20$ T rade $\% 20$ in $\% 20$ Goods $\% 20$ Agreement $\% 20$ (ATIGA).pdf (accessed on 10 May 2019).

$60 \mathrm{https} / / /$ www.economicsonline.co.uk/Global economics/Economic integration.html (accessed on 10 May 2019)

61 https://www.economicsonline.co.uk/Global_economics/Economic integration.html (accessed on 10 May 2019).

62 https://www.economicsonline.co.uk/Global_economics/Economic integration.html (accessed on 10 May 2019).

63 Bruno Zeller and Janko Nikolic, Trade Harmonisation-How Harmonised is it? Website: https://home.heinonline.org/ (accessed on 6 March 2019)

64 Bruno Zeller and Janko Nikolic, Trade Harmonisation-How Harmonised is it? Website: https://home.heinonline.org/ (accessed on 6 March 2019).

65 https://www.uncitral.org/pdf/e nglish/texts/sales/cisg/V1056997CISG-e-book.pdf (accessed on 10 May 2019)

${ }_{66} \mathrm{https} / /$ www.economicsonline.co.uk/Glob al economics/Economic integration.html (accessed on 10 May 2019).

67 https://www.ohada.org/index.php/en/ohada-reference-texts/ uniform-acts (accessed on 10 May 2019).

68 https://www.ohada.org/index.php/en/ohada-reference-texts/ uniform-acts (accessed on 10 May 2019).

69 Bruno Zeller and Janko Nikolic, Trade Harmonisation-How Harmonised is it? Website: https://home.heinonline.org/ (accessed on 6 March 2019).

70 Bruno Zeller and Janko Nikolic, Trade Harmonisation-How Harmonised is it? Website: https://home.heinonline.org/ (accessed on 6 March 2019).

71 Prabir De, Transit and Trade barriers in South Asia: Multilateral Obligations and Development Perspective. Website: https://home. heinonline.org/ (accessed on 6 March 2019).

72 Prabir De, Transit and Trade barriers in South Asia: Multilatera Obligations and Development Perspective. Website: https://home. heinonline.org/ (accessed on 6 March 2019).

73 Karl Marxen, The cycle of harmonisation-from domestic laws to the CISG and back. Website: https://home.heinonline.org/ (accessed on 6 March 2019).

74 http://www.ijbs.unimas.my/images/rep ository/pdf/Vol19-S3paper7.pdf (Accessed on 15 December 2018).

75 https://www.sicc.gov.sg/ (accessed on 15 December 2018).

\section{REFERENCES}

Andersen, C. The Global Jurisconsultorium of the CISG Revisited. http://www.cisg.law.pace.edu/cisg/biblio/ andersen7.html Accessed on: 13 May 2015.
Anomaly, J. Trust, Trade, and Moral progress: How Market Exchange Promotes Trustworthiness. Website: https:// www.cambridge.org/core/journals/social-philosophy-andpolicy/article/trust-trade-and-moral-progress-how-marketexchange-promotes-trustworthiness/754AE9CC31070717 2ABF5B719787E41B (accessed on 8 May 2019).

Goode, R., Kronke, H. and Mckendrick, E. 2015. Transnational Commercial Law. $2^{\text {nd }}$ edition. Oxford University Press.

http://saarc-sec.org/about-saarc (Accessed on 24 October 2018). http://saarc-sec.org/saarc-charter (accessed on 8 May 2019).

http://saarc-sec.org/areas_of_cooperation/area_detail/ economic-trade-and-finance/click-for-details 7 (accessed on 9 May 2019).

https://www.michigan.gov/documents/entireuccbook 188317 . pdf (accessed on 15 December 2018).

https://www.uncitral.org/pdf/english/texts/sales/cisg/V1056997CISG-e-book.pdf (Accessed on 15 December 2018.

https://www.saarcchamber.org (accessed on 24 October 2018).

https://www.saarcchamber.org/index.php?option=com_conte nt $\&$ view $=$ article $\& i d=374 \&$ Itemid $=500($ accessed on 24 October 2018)

https://www.saarcchamber.org/index.php?option=com_conte nt\&view $=$ article $\& i d=375 \&$ Itemid $=501 \#($ accessed on 24 October 2018).

https://www.miti.gov.my/miti/resources/fileupload/Writeup $\% 20$ on $\% 20$ ASEAN $\% 20$ Trade $\% 20$ in $\% 20$ Goods $\% 20$ Agreement\%20(ATIGA).pdf (accessed on 10 May 2019).

https://www.economicsonline.co.uk/Global_economics/ Economic integration.html (accessed on 10 May 2019)

http://www.ijbs.unimas.my/images/repository/pdf/Vol19-S3paper7.pdf (Accessed on 15 December 2018).

https://www.sicc.gov.sg/ (accessed on 15 December 2018).

https://www.ohada.org/index.php/en/ohada-reference-texts/ uniform-acts (accessed on 10 May 2019).

Next steps to South Asian Economic Union: A Study on Regional Economic Integration (Phase II) Commissioned by the SAARC Secretariat. Website: http://www.sasec.asia/ uploads/publications/next-steps-to-saeu.pdf (accessed on 9 May 2019).

Sellman, P. 2006. Revision Workbook: Law of International Trade, $4^{\text {th }}$ Edn, Old Baily Press, UK, pg. ix.

Thirty-Fourth SAARC Charter Day. Website: http://saarc-sec. org/assets/responsive_filemanager/source/Charter $\% 20$ Day\%20Messages/2018/Saarc.pdf (accessed on 9 May 2019).

Wethmar-Lemmer, M. Regional Harmonization of international sales law via the accession of the CISG and the importance of uniform interpretation of the CISG. Website: https:// home.heinonline.org/ (accessed on 6 March 2019).

Zeller, B. The significance of the Vienna Convention on the International Sale of Goods for the Harmonization and transplantation of international commercial law. https:// home.heinonline.org/ (accessed on 6 March 2019).

Zeller, B. and Nikolic, J. Trade Harmonisation-How Harmonised is it? Website: https://home.heinonline.org/ Accessed on: 6 March 2019.

Md. Habib Alam

Barrister-at-Law (Lincoln's Inn, UK)

Email: drmdhabibalam@gmail.com 